UNITED STATES DEPARTMENT OF THE INTERIOR

Harold L. Ickes, Secretary

GEOLOGICAL SURVEY

W. C. Mendenhall, Director

\title{
Bulletin 922-Q
}

\section{TUNGS'TEN DEPOSITS IN THE TUNGSTEN HILLS, INYO COUNTY CALIFORNIA}

\author{
BY \\ DWIGHT M. LEMMON
}

Strategic Minerals Investigations, 1940

(Pages 497-514)

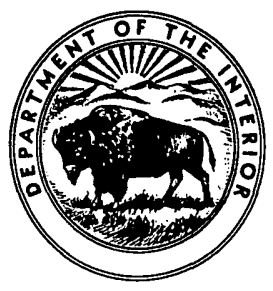

UNITED STATES

GOVERNMENT PRINTING OFFICE

WASHINGTON : 1941 



\section{CONTENTS}

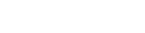

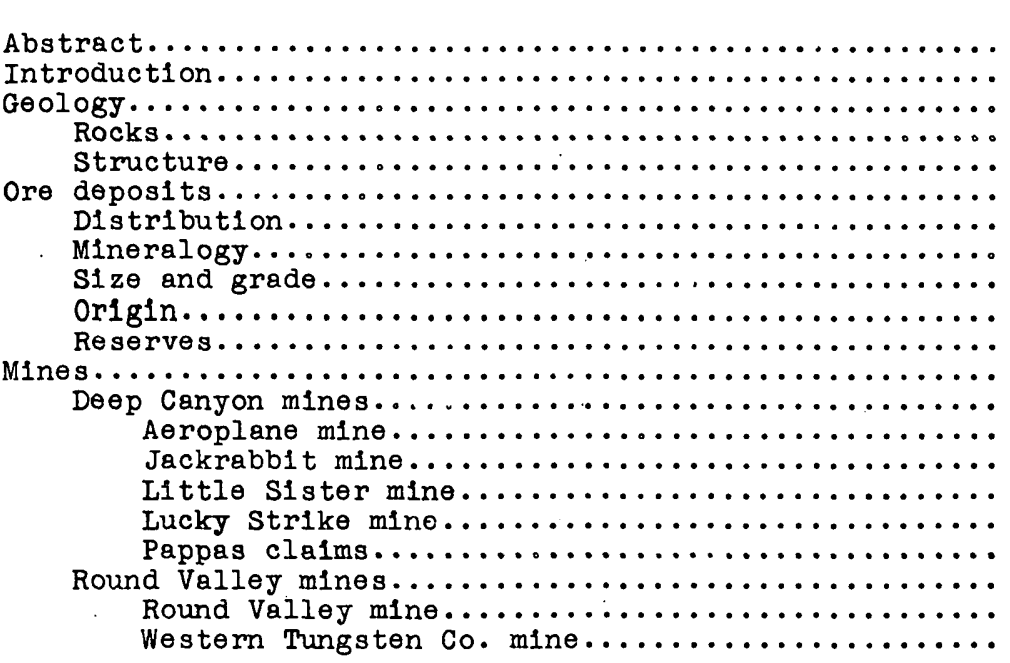

Page

497

497

499

499

503

503

503

503

505

506

506

506

507

507

509

509

510

510

511

512

513

\section{ILLUSTRATIONS}

Plate 72. Index map of southem California showing loca-

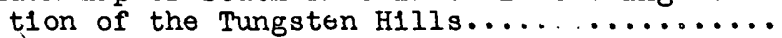

73. Geologic map of Deep Canyon area, Tungsten Hilis, Inyo County, Calif............ In pocket

74. Geologic map and section of Round Valley pendant, Tungsten Hills, Inyo County, Calif. In pocket

75. Plan and section of Little sister mine....... 508

76. Plan and section of Lucky strike mine....... 508

77. Geolog1c map of underground workings; Round

Valley mine................... In pocket

F1gure 72. Plan and section of Aeroplone mine......... 508

73. Geolog1c map of ma1n adit, Western Tungsten

Co. mine......................... 513 



\title{
TUNGSTEN DEPOSITS IN THE TUNGSTEN HILLS,
}

\section{INYO COUNTY, CALIFORNIA}

\author{
By Dwight M. Lemmon
}

\section{ABSTRACT}

In the Pungsten Hills, at the westerm base of the sierra Nevada, contact-metamorphic scheelite deposits occur in many small, isolated masses (called "pendants") of metamorphosed sedimentary rock surrounded by granite and quartz diorite. Although the age of the metamorphic rocks is unknown, the ores are genetically connected with the granitic rocks of probable late Jurassic age. Most of the ore bodies are small and are of relatively low grade, ranging from 0.5 to 1.0 percent of $\mathrm{WO}_{3}$; but they have been successfully operated because their favorable location permits mining at low cost. Although the known larger ore bodies are apparently nearly exhausted, numerous small, low-grade deposits, ranging in size from a few hundred to a few thousand tons, remain undeveloped. It is estimated that there is 100,000 tons of probable ore contalning 0.25 to 0.5 percent of $\mathrm{WO}_{3}$ in reserve. Additional ore bodies may be found at depth in the Round Valley deposit, for that pendant is large and persistent.

\section{INTRODUCTION}

The Tungsten Hills lie at the base of the Slerra Nevada 10 miles west of Blshop, Inyo County, Cal1f., in the Mount Goddard quadrangle (pl. 72). U. S. H1ghway 395 skirts the east edge of the hills, and several unimproved roads lead into them. The nearest rallroad is the narrow-gage Keeler branch of the Southerm Pacific Rallroad, which passes through Laws, 3 miles northeast of Bishop, and connects with the standard-gage line at Owenyo, 52 miles south of Laws. The Tungsten Hills are very favorably situated for cheap operation. They are easily accessible, have readily available electric power and water, are 
normally free of heavy snows in winter, and are topographically suited for low-cost mining by glory holes reached through adits. These deposits represent only a small part of the tungsten resources in Inyo and Mono Counties near Bishop. Other deposits will be described in separate reports now in preparation. Scheelite was discovered in the Tingsten Hills in 1913 as a result of small-scale gold-placer operations. Development was delayed unt11 1916, when operations were started at the Tungsten City group of claims of the Tungsten Mines Co. and the Standard Tungsten CO. and at the Round Valley mines on the north edge of the hills. The three properties were operated on a large scale until 1919, when tungsten prices collapsed. Between 1928 and 1931 some work was done on the Round Valley deposits by Cooper Shapley and associates and by the Tonopah Mining Co. of Nevada. In 1937 the Pacific Tungsten Co. (now the Western Tungsten Co.) operated a small mill on the west edge of the Round Valley pendant and did a little underground development. In $1940 \mathrm{El}$ Dlablo Mining Co. reopened the Round Valley mine. The Tungsten City properties along Deep Canyon, in the south-central part of the hills, have been operated by lessees since 1936, El Diablo Mining Co. working the large glory hole that had been operated by the Tungsten Mines Co. from 1916 to 1918 and the Tungsten Milling Co. (now Tungsten City Milling Co.) reworking the old mill tallings. For a short time the Tungsten Milling Co. also operated the Aeroplane mine, which had been worked by the Standard Tungsten Co. from 1916 to 1918. In $1940 \mathrm{El}$ Diablo Mining Co. ceased operations in the Deep Canyon area.

Although complete figures are not avallable, total production in the Tungsten Hills has probably exceeded 100,000 units of $\mathrm{WO}_{3}$. The only available published statistics, those for the year 1918, show a total of 42,977 units. At the indicated rate 
of production, the total to 1919 should be about 85,000 units, and recent production should ralse that to more than 100,000 units, 80 percent of which has probably come from the Deep Canyon mines.

Knopf $1 /$ made a preliminary report on these deposits in 1917. Hess and Larsen's $2 /$ somewhat more comprehensive descriptions were based on fleld work in 1918, after the mines had been operating for several years.

In the autumn of 1939 , in connection with the survey of the tungsten resources of the Bishop area, the writer, Mackenzie Gordon, Jr., and John V. N. Dorr $2 d$ made a reconnalssance geologic map of the Tungsten Hills, using as a base the Mount.Goddard topographic sheet enlarged to a scale of $1: 62,500$. They also prepared a detailed geologic and topographic map of the Round Valley pendant (pl. 74) by plane-table and alidade survey. In June 1940 a similar detalled map of the Deep Canyon area (pl. 73) was made with the assistance of Donald Wyant.

H. O. Johansen, manager of El Diablo Mining Co. properties on Deep Canyon, has permitted the use of maps prepared by the company's geologist, Mr.H. B. Bessac. R. E. Stolle, Earl

Falkner, A. L. Crowthers, A. E. Beauregard, B. W. Holeman, AI Stevens, Bert Shively, and J. E. Riley have given information and assistance.

\section{GEOLOGY}

\section{Rocks}

The Tungsten Hills are composed dominantly of grant te and quartz diorite, which enclose small masses or roof pendants made up of metamorphic rocks that are older than the grant te.

1/ Knopf, Adolph, Tungsten deposits of northwestern Inyo County, Calif.: U. S. Geol. Survey Bull. 640, Pp. 229-249, 1917.

2/ Hess, F. L., and Larsen, E. S., Contact-metamorphic tungsten deposits of the United States: U. S. Geol. Survey Bull. 725, pp. 268-274, 1921. 
The pendents consist of schists, quartzite, limestone, and skarn or "tactite"--a silicate-rich rock formed through the alteration of limestone. All these metamorphic rocks are derived from sedimentary rocks. Tilted remnants of a basalt flow cap a few summits on the north, and numerous dikes of aplite, diorite, and andesite cut the older rocks.

The granite is mainly a light-colored, even-grained rock composed essentially of feldspar and quartz with subordinate biotite, which is the only dark mineral. It varles in appearance and composition with the amount of absorbed sedimentary material. Certain minor portions of the granite, for example, appear to be the product of granitization of quartzite. These masses, more susceptible to weathering, turn rusty brown in contrast to the fresher color exhibited by most of the granite.

Although granite is by. far the most abundant intrusive ignedus rock, a small mass of coarse-grained, older quartz diorite, slightly more than half a mile in diameter, occurs in the mining area along Deep Canyon. "The quartz diorite is dark, for it is rich in biotite and hormblende. Plagioclase feldspar is its most ebundant mineral, but it also contains a smali amount of quartz. The rock weathers more readily than the granite and is soft and friable near the surface. Although quartz diorite predominates in the Deep Canyon mass, the rocks locally range from diorite to granodiorite and thereby may reflect the absorption of different kinds and amounts of the invaded rocks; for example, the quartz diorite near calcareous metamorphic inclusions sometimes contains abundant epidote for a few feet from the contact. On the hill across the canyon northwest of the Jackrabbit mine the epidotized diorite is the only vestige of a former pendant.

The aplite is a fine-grained, light-colored rock composed of quartz, feldspar, and occasional flakes of biotite. The 


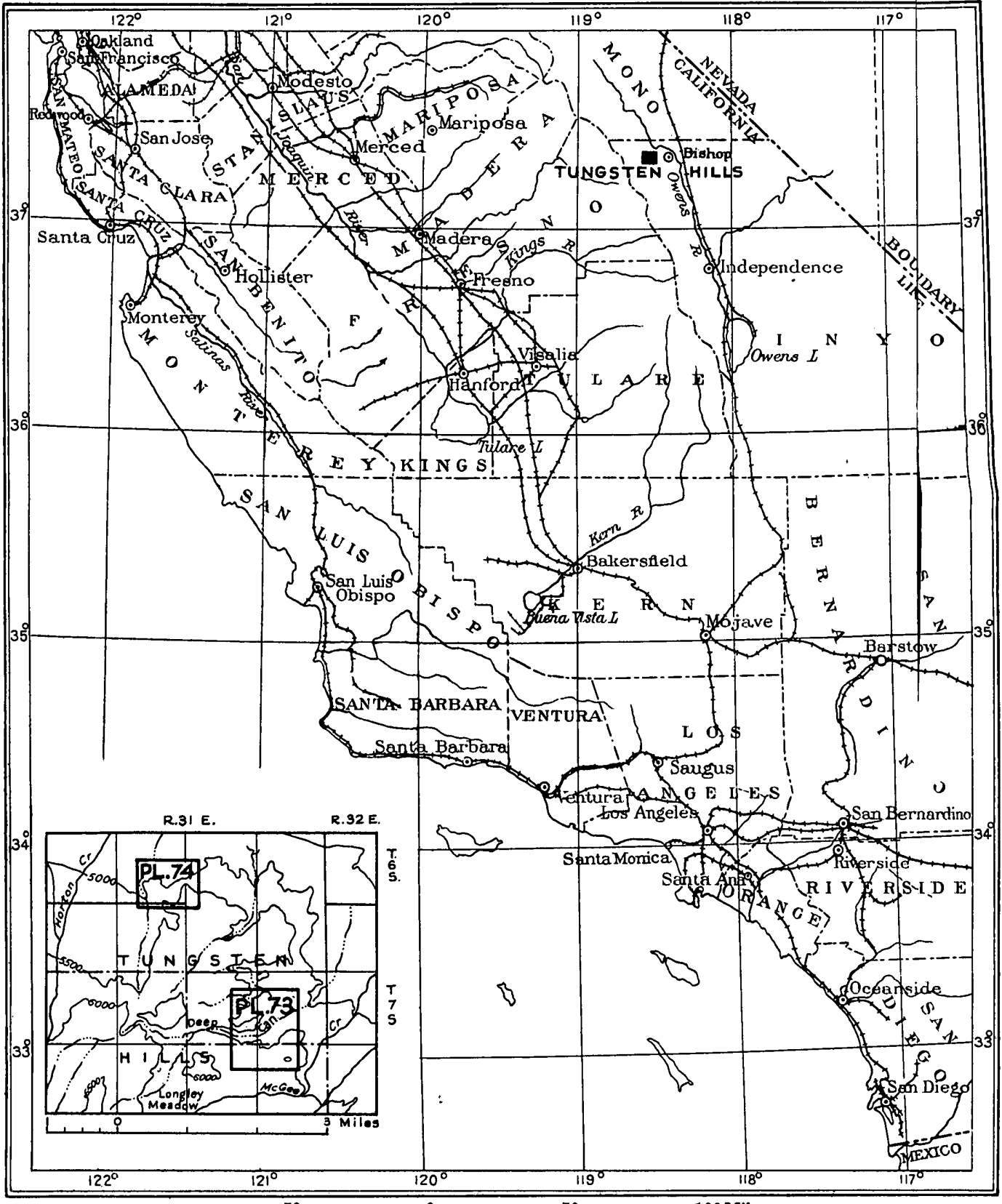

100 Miles 
andesite is dark gray, holocrystalline, and usually finegrained, although parts of it are porphyitic with small scattered feldspar phenocrysts in the dark, fine-grained groundmass.

The metamorphic rocks are belleved to be remnants of the former roof of the intrusive rocks and for this reason are called roof pendants. Erosion has removed most of the pendants, leaving only scattered masses.

The largest pendant is the one at Round Valley (pl. 74), which is about a mile long by a fifth of a mile wide. The only other important pendant area is along Deep Canyon (pl. 73) where the Tungsten City ore bodies are found. In this area the pendants extend to a much shallower depth than does the Round Valley pendant. Other smaller pendants with outcrops ranging In size from a few yards to many acres are distributed through the granite. The aggregate of the surface exposures is only a small fraction of the area occupled by granite. The exposures are much nearer the bottoms of the pendants than those in the High Sierra, but estimation of probable depth is difficult and open to great error. The larger pendants in the Tungsten H1lis may be several hundred feet deep, but this depth is insignificant when contrasted with the 5,000 feet of pendant exposed in the walls of Pine Creek in the sierra Nevada a few miles to the northwest.

The pendants are composed of metamorphosed sedimentary rocks that were originally shale, sandstone, and limestone but were changed by the intrusion of the granitic rocks to schist, hornfels, quartzite, skarm or tactite, and marble. The shale was altered to hormfels and $\mathrm{mica}$ and andalusite schists. Sandstone, depending upon its composition, became quartzite or quartz-mica schist. The calcareous rocks, limestone, shaly limestone, and calcareous shale, show the most varied altera- 
tion. Some beds are silicified and on casual inspection resemble quartzlte; others, which were probably nearly pure limestone, have been recrystallized to marble; and some of the thinbedded shaly limestone has become a spotted tactite and now consists of interlayered silicated and silicified limestone. Some beds are composed essentially of granular vesuvianite, whereas others have been entirely altered to a coarsely crystalline rock known as "tact1te," composed of variable amounts of garnet, epidote, diopside, amphibole, calcite, and quartz, which are usually accompanied by minute quantities of scheelite, apatite, sphene, and sulfides.

The age of the metamorphic rocks is unknown. Although no fossils have been found in the hills themselves, the fact that fosils from similar lithologic units in adjoining areas have ranged through the Paleozolc era suggests that the beds in the Tungsten Hills are also Paleozolc. Knopf $3 /$ collected Cambrian foseils from a patch of limestone and sandstone intruded by granite west of the town of Big Pine, 20 miles south of the Tungsten Hills, and Mayo 4 collected Devonian fossils from limestone in the Convict Lake Basin, 30 miles northwest. The limestone at the Pine Creek mine of the United States Vanadium Corporation, in the Sierra Nevada west of the Tungsten H1lls, contains Pennsylvanian fusulinids. No one has yet correlated these metamorphic rocks of the Sierra Nevada with the unaltered Paleozolc sedimentary formations of the Inyo Range.

The granite and quartz diorite are part of the Slerra Nevada batholith, Upper Jurassic in age, and the tungsten mineralization was probably contemporaneous with them. The basalt is early Plelstocene in age. $5 /$

3/ Knopf, Adolph, op. cit., p. 234.

4 Mayo, E. B., Fossile from the eastern Plank of the Sierra Nevada, California: Science, vol. 74, pp. 514-515, Nov. 21, 1931.

$5 /$ Knopf, Adolph, A geologic reconnaissance of the Inyo Range and the eastern slope of the Sierra Nevada, Calif.: U. S. Geol. Survey Prof. Paper 110, p. 74, 1918. 


\section{Structure}

The Tungsten Hills occupy a salient in the east front of the sierra Nevada. Bounded by faults, the hills form a slightIy less depressed part of the downfaulted Owens Valley graben. Geologlcally they are a part of the Slerra Nevada.

Within the hills there has been considerable faulting both before and after the granitic intrusion. The pre-granitic faults appear most closely related to the tungsten deposits. Individual pendants are broken by these faults, many of which have been penetrated by thin irregular dikes of granitic rock suggesting that magmatic stoping along the faults had an important part in the emplacement of the granitic rocks. The metamorphism, coupled with faulting, poor exposures, and the paucity of pendants, has made it impossible to plece together a stratigraphic section or to correlate the beds of different pendants.

\section{ORE DEPOSITS}

\section{Distribution}

Tungsten deposits are confined to the calcareous beds in the pendants and are restricted in large part to the portions of the calcareous beds that have been altered to tactite. Not all the tactite, however, contains tungsten, the ore occurring sporadically in bunches even in the favorable beds. Primary control of ore deposition seems to be the composition of the favorable calcareous beds and the distance from the igneous contact. The main ore bodies are in the Deep Canyon and Round Valley areas (pls. 73 and 74 ).

\section{Mineralogy}

The tungsten ores differ in composition, but all contain varying proportions of most of the following minerals, listed 
in approximate order of their abundance: garnet, amphibole, pyroxene, epidote, chlorite, quartz, calcite, phlogopite, scheelite, and sulfides--pyrite, sphalerite, and minor chalcopyrite. In most of the ore garnet is the most abundant mineral, const1tuting 80 percent or more of some of the rock. Occasionally in good ore epidote is the most prominent mineral, but ore of this type is relatively uncommon. At the Round Valley mine phlogopite has been abundant in the ore body in the large glory hole. Garnet forms dark red to brown zoned crystals, some of them an inch or more in diameter; it varies in composition from grossularite to spessartite. According to indices of refraction specimens from the Round Valley mine fall in the grossularitealmandite range, those from the Little sister mine in the almandite-spessartite range.

Epidote in well-formed crystals as much as 2 inches long is frequently found in the tactite ores, but it is commonly finergrained. The mineral is more abundant in the Deep Canyon area than in the Round Valley pendant. It also occurs as a finegrained alteration product of quartz diorite near the contact with calcareous rocks.

In some of the ores vitreous white quartz occurs in lenses a few inches to a few feet in length. In general these lenses contain no scheelite, but a quartz vein on the Van Loon claim at the west edge of the hills contains some scheelite in quartz. Pyroxene and hornblende in dark-green coarse-grained aggregates are common, especially in the two east ore bodies in the Round valley pendant. They can usually be alstinguished from each other only by microscopic examination. Phlogopite, the magnesian mica, is an essential constituent of the west ore body in the Round Valley mine.

Scheelite, the only ore mineral, is found in much of the ore as white euhedral crystals an eighth of an inch to an inch 
In diameter. These crystals are frequently platy, thus making the ores on surfaces of easy fracture appear to be of higher grade than they really are. The fact that the old mills in Deep Canyon made fair recoveries by grinding the ore to pass 8 to 14 mesh indicates that much of the scheelite was very coarse grained. The Tungsten City Milling Co., however, has increased the recovery from the tailings by finer grinding, which indicates that a part of the scheelite is fine-grained.

Pyrite, the commonest jellow sulfide of iron, is absent from most of the ore but constitutes as much as 20 percent of the rock in the bottom of the glory hole at the Aeroplane mine. Sphalerite, zinc sulflde, occurs in dark resinous or black grains, which are abundant in the small glory hole at the top of the hill west of the Little Sister glory hole. Molybdenite, molybdenum sulfide, is probably also.present in traces in some of the ore, for concentrates contain minute amounts of $\mathrm{MOO}_{3}$.

\section{$\underline{\text { S1ze and grade }}$}

Ore bodles have ranged in bulk from a few tons to a hundred thousand tons. The largest ore body extracted to date--that in the Little sister glory hole--was 300 feet long, 100 feet wide, and 150 feet deep.

Past production records indicate that on the average slightIy over 0.5 percent of $W 0_{3}$ has been recovered from the ore mined, although large specimens containing as much as 10 percent of $\mathrm{WO}_{3}$ have been found locally. The recovery of scheelite from the mill tallings in Deep Canyon, however, suggests that these ore bodies may have contained considerably more than the reported recovery of 0.5 percent of $\mathrm{WO}_{3}$. There are also bodies containing considerable tonnages of ores of submarginal grade, 0.25 to 0.4 percent of $\mathrm{wO}_{3}$, but these ore bodles have not been mined. 


\section{OrIgln}

Limestone in contact with intrusive granite occurs in all the productive areas in the Tungsten Hills. The scheelite evidently was deposited during a late. stage of the granitic intrusion and was localized by reaction between the tungsten-bearing solutions and limestone. The solutions may have penetrated along contacts after partial solidification of the granitic rock.

\section{Reserves}

Very little ore is proved or blocked out in the Tungsten Hills, but tonnage of probable ore is perhaps as much as 100,000 tons. The grade of this probable ore is low, averaging between 0.25 and 0.5 percent of $\mathrm{WO}_{3}$, although portions of the ore are undoubtedly of somewhat higher grade. The probable ore is distributed through at least a dozen small pendants, no one of which contains a large tonnage and most of which have been prospected on the surface only. The depth to which these pendants extend is problematical. The Round Valley pendant shows the most promise of providing a large tonnage, for it extends to a greater depth than the others.

The low grade of the ores, coupled with the small size of many of the ore bodies, necessitates a falrly high price for tungsten to insure successful operation. Central milling facilities are essential for economical production from the smaller bodies.

\section{MINES}

The main tungsten mines are located along Deep Canyon ( $p l$. 73) in the south-central part of the hills and in the Round Valley pendant at the north edge of the hills (pl. 74). The Deep Canyon mines, which have been most productive and have 
recelved the most development, were inactive in June 1940. At that time the Round Valley mine was being operated and the Western Tungsten Co. mine was being prepared for production.

\section{Deep Canyon mines}

The principal mines along Deep Canyon are the Aeroplane, Jackrabbit, Little Sister, and Lucky Strike. In addition there are small undeveloped ore bodies on the Pappas claims (Tungsten Blue group) north of the Jackrabbit mine and on the Van Loon claims at the west edge of the hills, west of the area shown on plate 73 .

\section{Aeroplane mine}

Two main ore bodies have been developed in the Aeroplane mine: a south ore body and a north ore body. The south ore body, which is the larger, is developed by a large glory hole reached by two adits 50 and 195 feet below the outcrop (fig. 72). The tactite pendant is 24 feet wide in the lower adit, the portal of which is at the mill, but only 7 feet of the tactite contains scheelite at this level, and the ore is submarginal, probably averaging about 0.25 percent of $\mathrm{WO}_{3}$. It is reported that the bottom of the glory hole, which is above this level, still contains some ore, although an unusually large amount of pyrite, probably 20 percent, is also present. The glory hole at the surface is 30 feet wide and 165 feet long. It $1 \mathrm{~s}$ about 145 feet deep. On the north edge of the glory hole the ore body, which is nearly vertical, ends against a premineral fault containing a quartz diorite dike. The tactite, which contains the ore body, is cut of $f$ by the main mass of quartz diortte 100 feet south of the glory hole. The ore is bounded by quartzite on the east and west sides. 
A second, narrow, scheelite-bearing zone is cut near the mouth of the upper adit. This zone continues northward along the face of the hill for 400 feet to the north ore body, which is developed by a long adit and a small stope to the surface, about 100 feet above. Ore 5 feet thick in banded limestone and

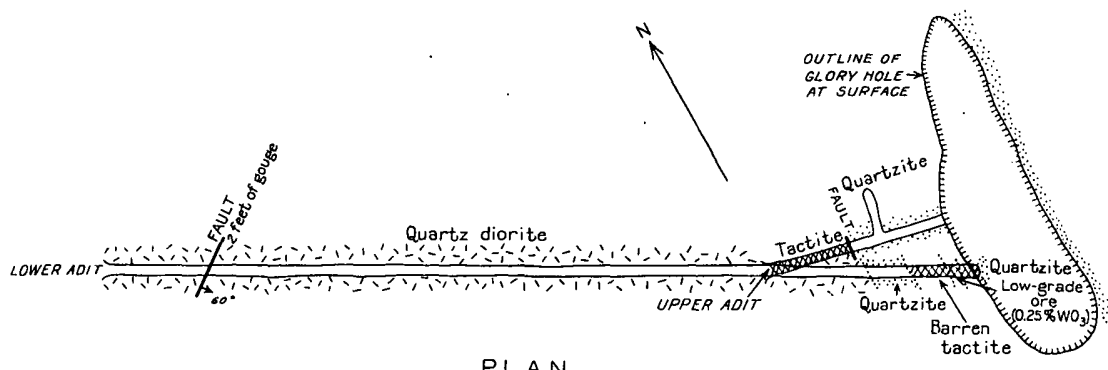

PLAN

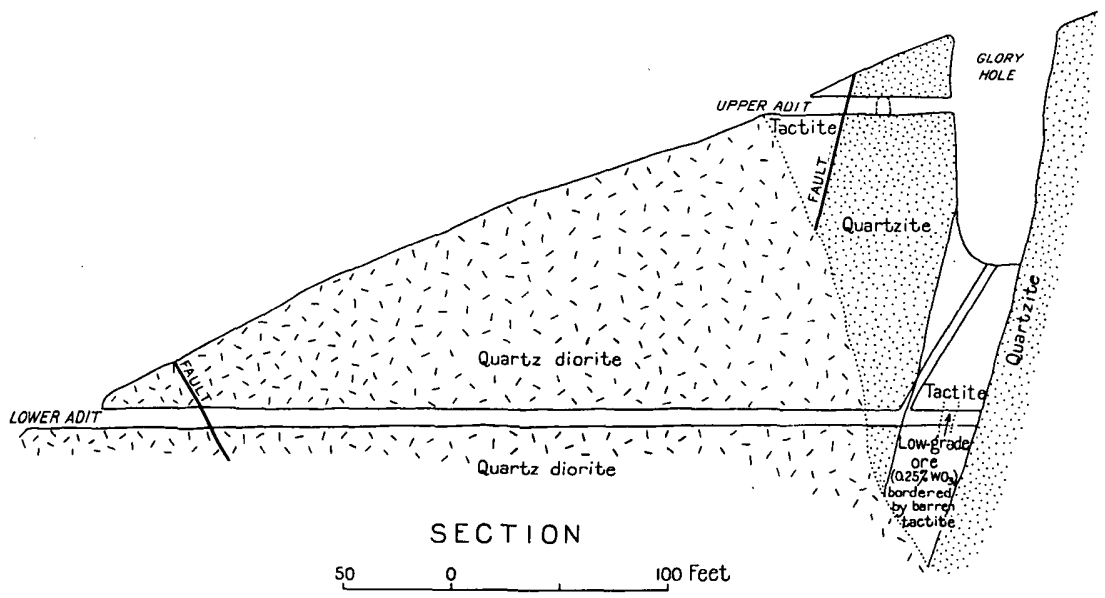

Figure 72.--Plan and section of Aeroplane mine.

tactite was stoped for a maximum length of about 75 feet and a depth of about 50 feet along a bed that dips $30^{\circ} \mathrm{SE}$. No ore is exposed in the adit 100 feet below, but there may be other undiscovered ore bodies along the strike of this bed in both directions. The hanglng wall of the ore body is marble.

The hill northeast of the Aeroplane mine; where the Tiptop claims are located, is capped by a gently dipping tactite body. 

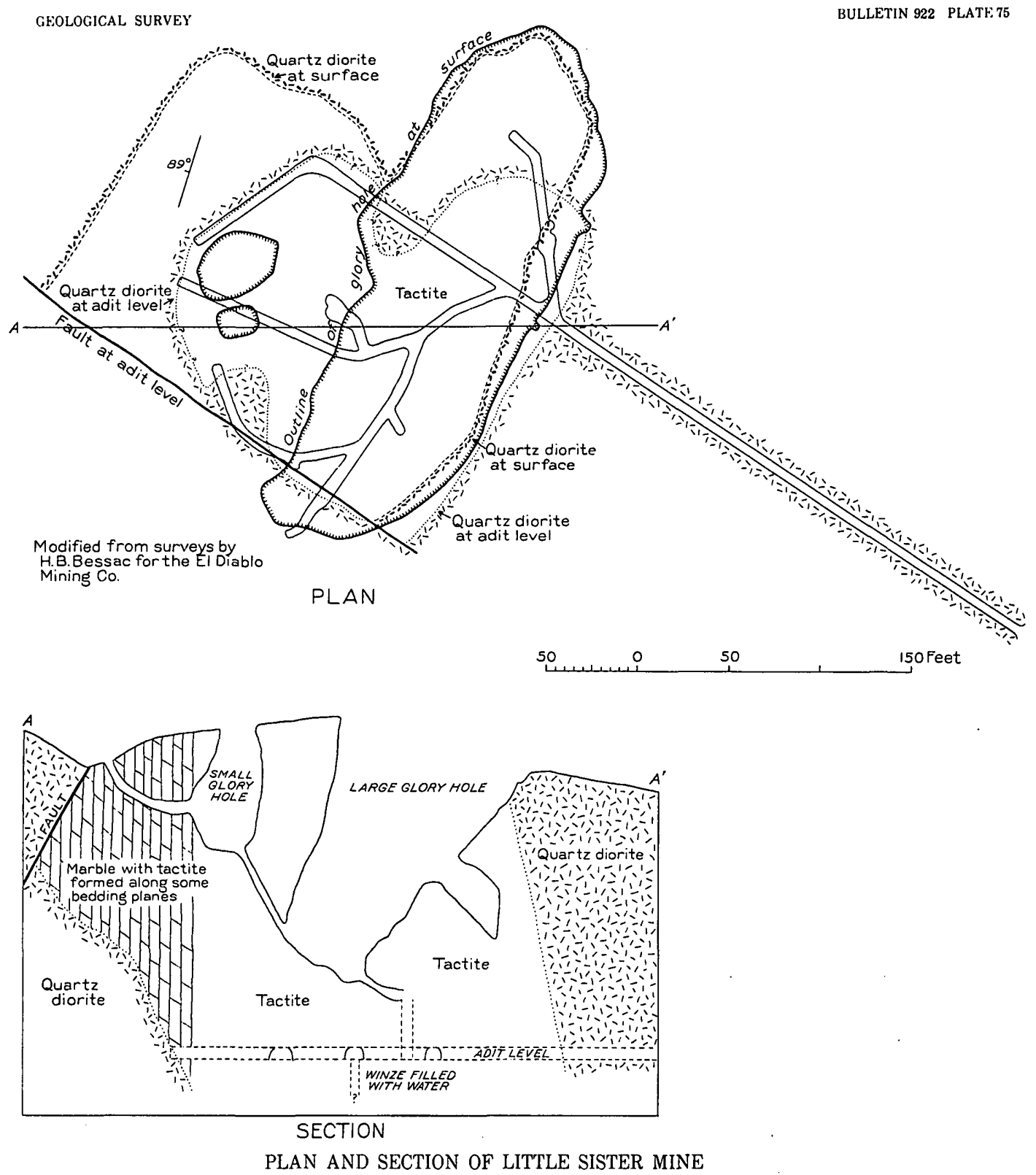


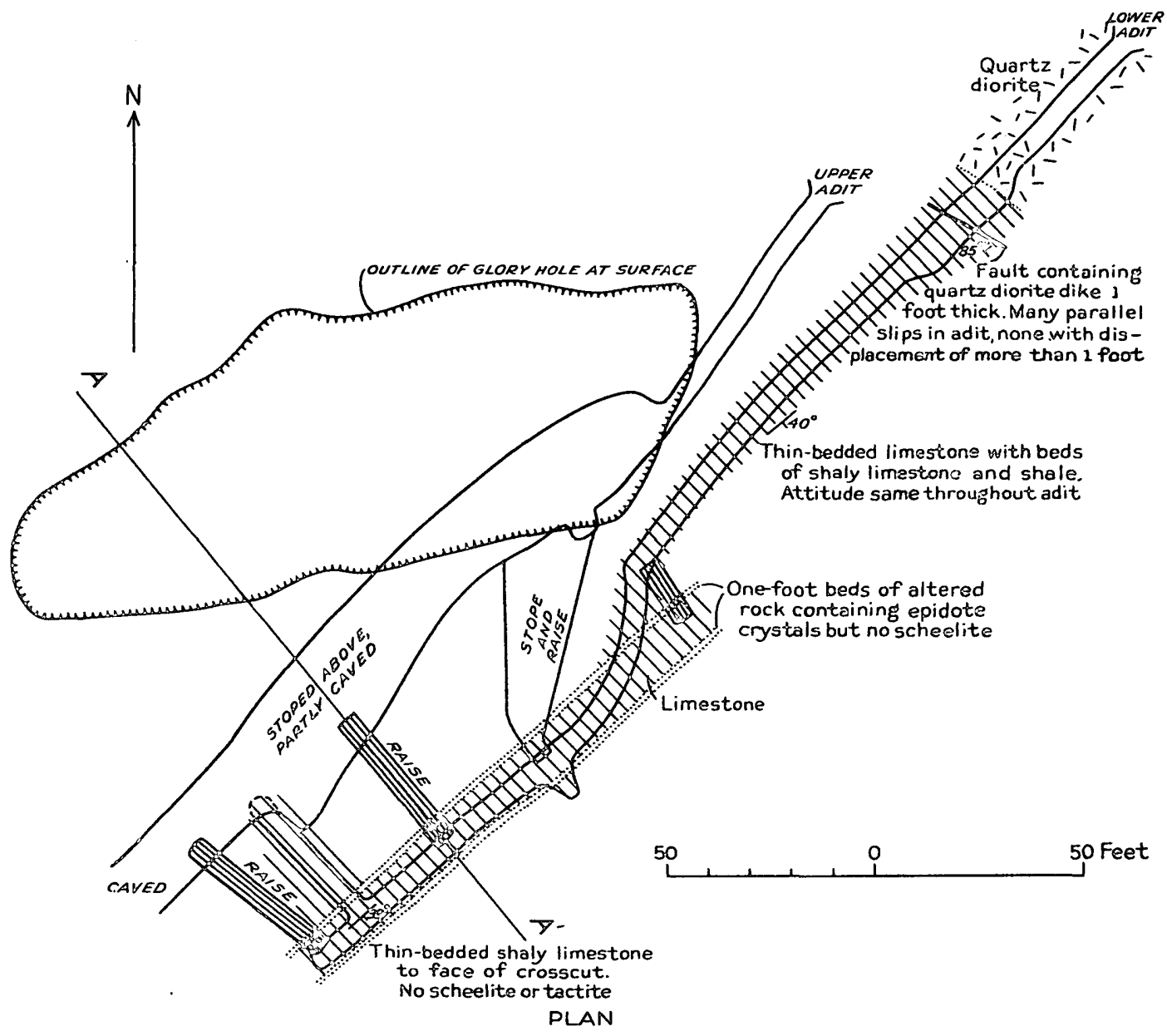

NW.

SE.

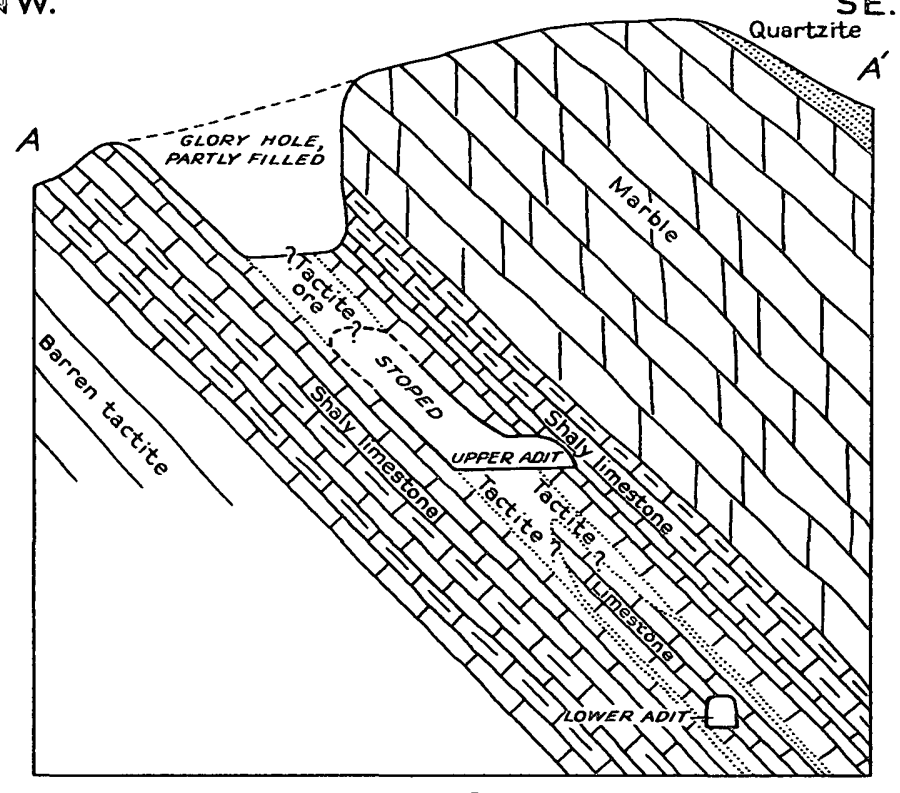

SECTION

PLAN AND SECTION OF LUCKY STRIKE MINE 
Although a few prospect holes and adlts have been driven into it, no ore of commercial grade has been founc. Low-grade scheelite occurs all along the contact, and there is a considerable tonnage that might average 0.1 percent of $\mathrm{WO}_{3}$. Commercial ore bodies might be found here by extensive prospecting.

\section{Jackrabbit mine}

The Jackrabb1t mine, developed by two glory holes and one main adit 200 feet long, has supplied a small amount of ore from two ore bodies, which trend at right angles to each other. The structure, though obscure, suggests faulting. No ore is found at the adit level, although some portions of the tactite extend that deep. There is still some ore above this level, and at the surface broad outcrops of gamet rock contain considerable epidote. This property was worked in 1916-18 by the Tungsten Mines Co., whlch also operated the Little Sister and Lucky Strike mines.

\section{Little sister mine}

The Little Sister mine, on the Tungsten City No. I claim, has had the largest production of any mine in the Tungsten Hills. It is developed by a long adt and a large glory hole (pl. 75) in which the ore body is bounded by quartz diorite on the north, east, and south and by limestone and tactite on the southwest. The southeastern contact is a postmineral fault that follows the canyon in a northeasterly direction. Ore continued to the adit level, and a winze, now full of water, was sunk in tactite beneath the adit, but no ore was stoped from 1t. The ore consists largely of garnet with small lenses of quartz and sparsely disseminated scheelite. Ore of workable grade is apparently exhausted, although more might be found beneath the lower adit level. 
A smaller glory hole has been opened in the tactite at a different horizon 50 feet southwest of the main glory hole. Along the ridge to the west small ore bodies have been mined from several of the small tactite bodies. The first small glory hole west of the Little sister claim contains abundant sphalerite in the tactite, but sulfides do not appear to be abundant in any of the other bodies.

\section{Lucky Strike mine}

The Lucky Strike mine, on the south side of Deep Canyon several thousand feet west of the Little sister mine, is developed by two adits 90 and 135 feet below the outcrop and by a glory hole (pl. 76). The ore body, whlch dips gently southeastward, is in a single bed of tactite 10 to 20 feet thick. Ore does not continue to the lower adit although the tactite persists. At the surface the same ore bed appears along the strike to the southwest in several prospects separated by bodies of quartz diorite. These prospects may still contain some ore.

At the surface the hanging wall of the ore body consists of a thick bed of marble, which is bordered conformably by quartz1te and schist bands along the ridge to the southeast. The footwall is partly silicated limestone. The large mass of marble, which contains no scheelite or tactite, is cut off by quartz diorite along the strike in both directions.

\section{Pappas claims}

A scheellte ore body has been found on the hill across the canyon north of the Jackrabbit mine, on the Pappas claims. Development consists of two prospect shafts 8 and 15 feet deep. The ore body, which is nearly vertical, appears to be about 10 feet thick and extends nearly 100 feet northwestward. The scheelite occurs in fairly large crystals along shear zones and 
fractures in tactite and to a lesser extent is disseminated in tactite. The ore, which probably contains 0.25 to 0.5 percent of $\mathrm{WO}_{3}$, consists dominantly of epidote but also contains abundant amphibole. The quartz diorite adjoining the tactite pendant $1 \mathrm{~s}$ altered for 10 feet to an epldotized diorite.

\section{Round Valley mines}

The Round Valley pendant (pl. 74) is about 4,000 feet long and 600 to 1,000 feet w1de. It is surrounded by granite on all sldes except the west, where it is covered by alluvium. The metamorphic rocks within the pendant consist mainly of mica schist but include also tactite and limestone. The strata strike at right angles to the trend of the pendant, and some of the beds have probably been repeated by folding or faulting. Metamorphism and poor exposures make correlation difficult. Aplite dikes are abundant on the west side of the pendant, and an andesite dike cuts through the center.

Scherlite has been found in five different beds along the north contact, but along all of the beds it appears to diminish in quantity with increasing distance from the contact. No ore has been mined more than 100 feet away from the granite. Of the f1ve known ore beds, one is in the Westerm Tungsten Co. mine at the west end of the pendant, three are in the Round Valley mine, and one, undeveloped, is between the two mines. At the Round Valley mine the contact between granite and pendant is for a considerable distance a south-dipping fault, and some scheelite mineralization has occurred along the fault wherever the beds are slightly calcareous; but the mineralized rock is normally of low grade and only a few inches to a few feet wide. The known ore zones are confined to the favorable calcareous beds that strike perpendicular to the contact. 


\section{Round Valley mine}

The Round Valley mine, which has been the most productive In the pendant, contains three ore beds developed by three adits, a glory hole, and an incline shaft 65 feet deep beneath the glory hole (pl. 77). Each of the ore beds has been productive, but the western one, mined through the glory hole, has provided the main tonnage. This body, 100 feet long and 20 feet wide, dips $45^{\circ} \mathrm{W}$. Workings at the bottom of the incline shaft contain no commerclal ore along the downward extension of this body although ore, now being extracted through the shaft, is still present in the bottom of the glory hole. Part of the ore in the glory hole consisted largely of phlogopite mica with quartz.

The second, central ore bed, composed of tactite ore, has been crosscut by an extension of the adit beneath the glory hole as well as by a shorter adit farther east. Part of the body has been stoped from the upper adit, but the same bed in the lower adit is of too low grade to be productive.

The third, east bed is not connected with other workings. A large underground stope in this bed, still open, was never extended to the surface. Ore remaining in the chutes and in pillars contains large scheelite crystals in a tactite composed mainly of hornblende, pyroxene, and garnet.

Still farther east and extending across the pendant are other thick tactite beds that may contain scheelite.

Although the scheelite content of each of the ore beds has decreased in depth, there seems no valid geologic reason why other bunches of ore should not be found still deeper, for the pendant and favorable beds extend downward probably several hundred feet.

No ore has been found on the southern contact of the pendant with the granite, and there has been very little prospect- 
ing along 1t. There may be undiscovered ore along this contact, though the absence of faulting along the contact may possibly have prevented passage of tungsten-bearing solutions.

\section{Western Tungsten Co. mine}

The Western Tungsten Co. mine (formerly Pacific Tungsten Co.) is developed by an adit 170 feet long, 270 feet of arifts,

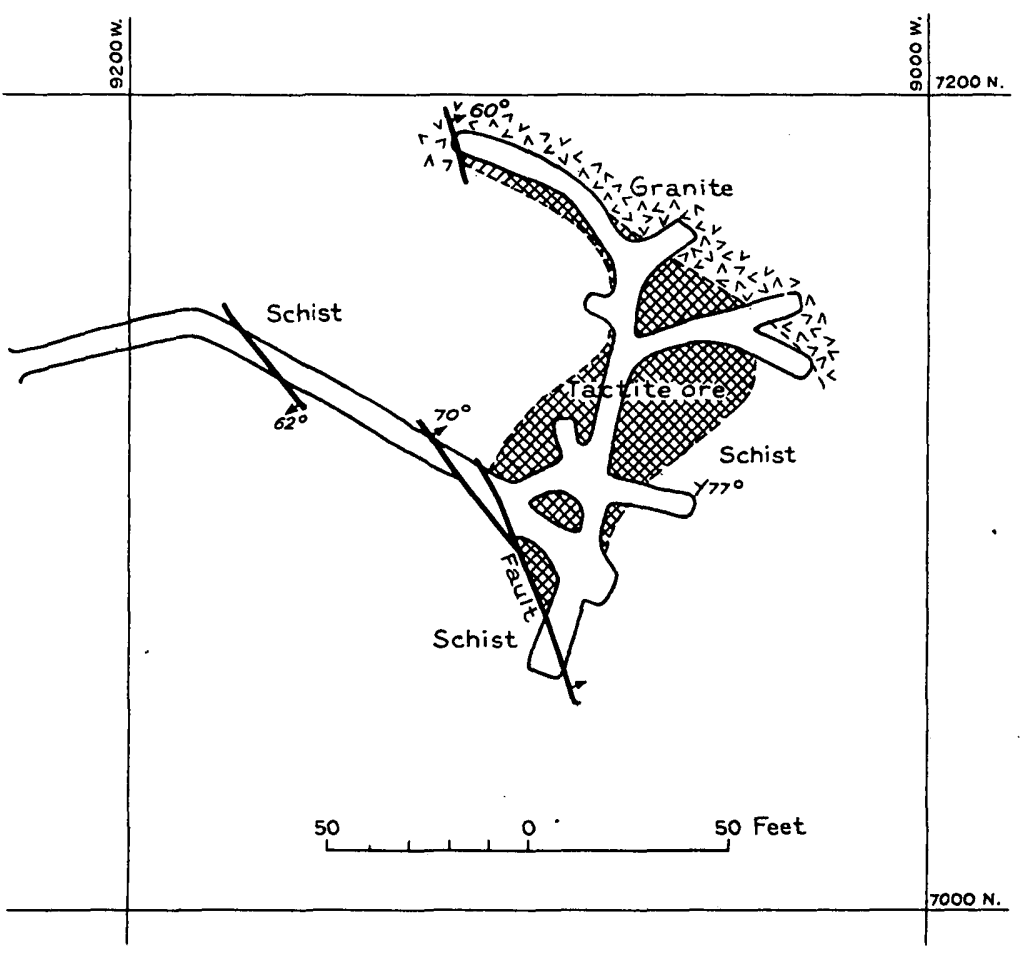

Figure 73.--Geologic map of main adit, Western Tungsten Co. mine.

a small glory hole, and numerous raises (fig. 73). The ore body has decreased. In length from 200 feet at the surface to 80 feet at the adt level about 80 feet below. In the adit the ore is 35 feet wide. The decrease in length is caused by the convergence of the granite contact, which dips $45^{\circ} \mathrm{S}$., with the north-dipping fault, beyond which no work has been done to the south. The ore body above the adit contains roughly 25,000 
tons, the average grade of whlch is probably less than 0.5 percent of $\mathrm{WO}_{3}$. The depth to which ore extends below the adit is unknown, although it is probably at least 50 feet and may be 100 feet or more. The pendant apparently extends deeper than any other in the district. 